\title{
TOXIC METALS EXTRACTION DURING POTATO FERMENTATION
}

\author{
Sioma I.B., Tashyrev A.B., Govorukha V.M., Prekrasna Y.P.
}

\begin{abstract}
According to the thermodynamical prognosis developed by us the investigation of the interaction of BacillusClostridium community and six representative metals was performed. To representative metals we refer: oxidisers $\left(\mathrm{CrO}_{4}{ }^{2-}\right)$, substitutes $\left(\mathrm{Ni}^{2+}, \mathrm{Co}^{2+}\right)$ and combined action metals that combine the characteristics of both oxidizers and substitutes $\left(\mathrm{Cu}^{2+}, \mathrm{Hg}^{2+}, \mathrm{Fe}^{3+}\right)$.

The natural soil hydrogen-producing microbial communities appeared to be resistant to the metals in their high total concentration of $120 \mathrm{mg} / \mathrm{l}$ and also able to extract these metals from the solution (up to $96 \%$ ).

The obtained regularities are the base for the development of new combined biotechnologies, allowing to neutralize ecologically hazardous food wastes, treat metal contaminated sewages and simultaneously obtain environmentally friendly energy source - hydrogen.
\end{abstract}

Key words: metal resistant communities, sewage treatment, toxic waste destruction.

\section{INTRODUCTION}

The industrial development leads to constant increasing of the solid waste volume, especially food waste that pose a serious hasard as the result of their uncontrolled rotting. Another strategic problem demanding immediate solution is the detoxication of metal contaminated sewages. Nowadays there are microbial biotechnologies of removal and accumulation of such metals as $\mathrm{Pb}, \mathrm{Zn}, \mathrm{Cd}, \mathrm{Cr}, \mathrm{Cu}, \mathrm{Ni}$, $\mathrm{Mn}, \mathrm{Al}, \mathrm{Fe}[9 ; 4 ; 6 ; 2 ; 1]$. The main problem of these technologies is discovering the microorganisms that are widely spread in nature and resistant to higher than natural concentrations of metals. The third worldwide issue is the search of efficient industrial technologies of obtaining environmentally friendly energy sources, for instance, molecular hydrogen $[8 ; 13]$.

The purpose of our investigation was combining of three useful results: neutralisation of solid food waste, toxic metals extracting from the solution; obtaining molecular hydrogen - in one process of solid food waste fermentation by soil community of spore-forming microorganisms.

Anaerobic destruction of organic polymeres, of which solid food waste consist, can develop in two metabolic ways: metane or hydrogen fermentation. Hydrogen fermentation has a range of advantages over methane fermentation: it does not require such strict process control, develops faster and does not produce toxic side-products $[8 ; 13]$.

Hydrogen fermentation is performed by a wide range of microorganisms. Spore-forming anaerobic bacteria of Clostridium genus are the most likely to be used in the biotechnologies. Their advantages are as follows: microorganisms of Clostridium sp. Are common components of soil ecosystems and widely spread throughout the world; due to spore forming they are resistant to negative factors; the microorganisms of Clostridium sp. can quickly and efficiently hydrolise a wide range of natural polymeres of plant and animal origin (cellulose, starch, proteins etc.) $[3 ; 8]$.

Hydrogen-producing microorganisms also can be used for the extraction of a wide range of toxic metals from industrial sewages. These metals include $\mathrm{Cu}^{2+}, \mathrm{Hg}^{2+}, \mathrm{Ni}^{2+}, \mathrm{Co}^{2+}, \mathrm{CrO}_{4}{ }^{2-}$ i $\mathrm{Fe}^{3+}$. The mentioned metals combine all types of negative effects of metals on microorganisms. By these types metals are divided into three groups [5,6]: oxidizers $(\mathrm{Cr}(\mathrm{VI}))$, substitutes (Co(II) and $\mathrm{Ni}(\mathrm{II}))$ and combined action metals ( $\mathrm{Hg}(\mathrm{II}), \mathrm{Cu}(\mathrm{II})$ and $\mathrm{Fe}(\mathrm{III})$ ).

Oxidizing metals, such as $\mathrm{Cr}(\mathrm{VI}), \mathrm{V}(\mathrm{VI})$, $\mathrm{Mo}(\mathrm{VI}), \mathrm{Tc}(\mathrm{III})$ are the cause of high RedOx potential and lead to irreversible oxidation of microbial structure components and enzymes. Substitutes irreversibly substitute metals in enzymes active centres - $\mathrm{Co}$ (II), Ni(II), $\mathrm{Cd}(\mathrm{II}), \mathrm{Pb}$ (II), Zn(II) etc. Combined action metals combine the characteristics of both oxidizers and substitutes $\mathrm{Hg}$ (II) and $\mathrm{Cu}$ (II) [12].

In the process of polymere substrate (potato starch) fermentation microbial communities reduce RedOx potential to negative values $\left(\begin{array}{llll}-200 & \ldots & -300\end{array}\right.$ $\mathrm{mV}$ ) and create the conditions for unavoidable reduction of high-potential metals. In a binary system "metals-oxidizers" - "microorganisms" microorganisms are the electrone donors and reduce soluble oxidizers $\left(\mathrm{CrO}_{4}{ }^{2-}\right)$ and combined action metals $\left(\mathrm{Cu}^{2+}, \mathrm{Hg}^{2+}\right)$ to insoluble, thus, non toxic compounds $\left(\mathrm{Cu}_{2} \mathrm{O}, \mathrm{Cr}(\mathrm{OH})_{3} \mathrm{nH}_{2} \mathrm{O}, \mathrm{Hg}^{0}\right)$.

Substitute metals $\left(\mathrm{Ni}^{2+}, \mathrm{Co}^{2+}\right.$ etc.) cannot be reduced by microorganisms as their reduction potential is lower than $-414 \mathrm{mV}(\mathrm{pH}=7,0)$ [11]. Although, under neutral and mild alkaline conditions cations of these metals form insoluble compounds with microbial exometabolites $\left(\mathrm{CoCO}_{3}, \quad\left[\mathrm{Ni}^{2+} \cdot\right.\right.$ protein $]$ and other 
complexes) and are actively absorbed by cell walls as the result of substituting metals $\left(\mathrm{Ca}^{2+}, \mathrm{Mg}^{2+}\right)$ in the cells walls of microorganisms.

In view of this metabolically active microbial communities are simultaneously realising all theoretically assumed types of interaction with metals that lead to extraction of the latter from solutions (sewages, etc.).

To create the low potential donor system we have chosen potato, which is also a model of ecologically hazardous food wastes. In the process of potato starch fermentation not only the low potential conditions are obtained $(-200 \ldots-360 \mathrm{mV})$, needed for metals extraction, but also molecular hydrogen - energy source - is produced. Thus, by fermenting potato with Bacillus-Clostridium "hydrogen" community we achieve the following positive effects:

1. Reducing of mass and volume of ecologically hazardous solid food waste (starch hydrolysis);

2. Environmentally friendly energy source synthesis - hydrogen;

3. Obtaining of the concentrate of commercially valuable metals.

\section{MATERIALS AND METHODS}

Research objects: spore forming microbial community (Bacillus and Clostridium), model food waste (potato), toxic metal solution.

Bacillus and Clostridium microbial community was obtained by cultivation of $1 \mathrm{~g}$ of dry Chornozem soil suspended in $10 \mathrm{ml}$ of tap water. The mixture was boiled for 5 minutes to destroy the cells of nonspore forming microorganisms. Then $50 \mathrm{ml}$ of liquid medium was added. One litre of the medium contained: $10 \mathrm{~g}$ of starch, $2.0 \mathrm{~g} \mathrm{~K}_{2} \mathrm{PO}_{4}, 0.2 \mathrm{~g} \mathrm{MgSO}_{4}$, $2.0 \mathrm{~g} \mathrm{NH}_{4} \mathrm{Cl}(\mathrm{pH}=7,0)$. Cultivanion was performed in hermetically shut flasks under $21^{\circ} \mathrm{C}$. The content of the community was checked by microscopy and by cultivation of 1:10 dilutions on agar plates.

For the experiment rotten potato was peeled, chopped, boiled for 5 minutes and placed into a sterile flask, then boiled water and innoculate (obtained cultivating the solution of Chornozem soil) was added. Cultivanion was performed in hermetically sealed flasks under $21^{\circ} \mathrm{C}$.

The metal ions were as follows: $\mathrm{Cu}^{2+}, \mathrm{Hg}^{2+}$, $\mathrm{Ni}^{2+}, \mathrm{Co}^{2+}, \mathrm{CrO}_{4}{ }^{2-}$ and $\mathrm{Fe}^{3+}$ in the total concentration of $120 \mathrm{mg} / \mathrm{l}(20 \mathrm{mg} / \mathrm{l}$ of each metal ion). This concentration corresponds with the concentration of metals in real industrial sewages $100-120 \mathrm{mg} / 1$.
The microbial metabolism was measured after following values: $\mathrm{pH}$, Eh, biomass growth at the optical density (D, opt. dens. units). Additionally were measured the metals concentrations and hydrogen production.

RedOx potential (Eh) and $\mathrm{pH}$ of the medium were measured by $\mathrm{pH}$-meter-millivoltmeter "pH-150 MA" using three electrodes. For Eh measurement we used platinum electrode "ЭПВ-1" matching with chloride silver flowing comparison electrode “ЭВЛ-1М3”, and for $\mathrm{pH}$ measurement - glass electrode "ЭСК-10603/4". Optical density was measured using photocolorimeter "КФК-2МП", wavelength $\lambda=540 \mathrm{~nm}$, optical cross $3 \mathrm{~mm}$. Tap water was used as the control solution.

Metals were added to the medium on the third day of cultivation in the fase on active potato destruction. Under these conditions RedOx potential reached the lowest value levels $(-200 \ldots-300 \mathrm{mV})$, that improved metal extraction from the medium.

Metals concentration was measured in the supernatant using photocolorimeter КФК-2МП.

Measuring method for divalent metals concentration is based on formation of coloured complexes of divalent metals with PAR (piridilazorhezorcinole) [5].

$\mathrm{Cr}(\mathrm{VI})$ concentration was measured using DFC (diphenylcarbazide) [5].

$\mathrm{Fe}^{3+}$ ions were measured with potassium rhodanide in the acid medium [10].

All experiments were performed in three variants of both experimental and control variations, on which were based the standart deviations, calculated by the general formula:

$$
\sigma=\sqrt{\frac{1}{N} \sum_{i=1}^{N}\left(x_{i}-\mu\right)^{2}}
$$

\section{RESULTS AND DISCUSSION}

Thanks to the thermodinamic prognosing method we have developed the methodology base for the simultaneous solution of three environmental problems (reducing of food waste volume; obtaining energy source - $\left(\mathrm{H}_{2}\right)$ and extraction of the most toxic metals from solutions). Unlike time-consuming and unstable methane fermentation of polymeric compounds, microbial Bacillus-Clostridium community quickly and efficiently destroys polymeric compounds and reduces RedOx potential to significally low values. The biological role of Bacilli was providing obligatory anaerobic 
Clostridia with the optimal growth conditions. The role of Clostridia was reducing the RedOx potential to the low values, optimal for metal reduction, further potato destruction and hydrogen production. Furthermore, metals-substitutes were sorbed by the cells and sedimentated by exometabolites.

The first signs of potato destruction were seen on the first day of cultivation. These were foaming on the medium surface and floating of potato bits. It is known that acidification of the medium by metabolic products inhibits potato hydrolyse and hydrogen production [8]. Therefore to prevent inhibition the culture medium was neutralized by the saturated solution of $\mathrm{Na}_{2} \mathrm{CO}_{3}$.

Active fermentation was taking place during first four days (Figures 1,2 and 3). During first two days RedOx potential decreased sharply from +380 $\mathrm{mV}$ to $-260 \ldots-270 \mathrm{mV}$, and $\mathrm{pH}$ decreased form 7,0 to $4,5-4,7$, which signifies active microbial metabolism under obligatory anaerobic conditions [7]. Another sign of active microbial growth was significant increase of optical density during three days (from 0,3 to 2,8 - 3,5 units) (Figure 3 ).

Adding metals to the medium did not make significant effect on the $\mathrm{pH}$ level. It remained in the range of 6.5-6.2 during 24 hours after adding metals (Fig. 2).

On the other hand, RedOx potential sharply increased and hour after adding of the metals( from -230 to $+100 \mathrm{MB}$ ) (Fig. 1).
In 24 hours after metal adding the RedOx potential gradually reduced to its previous value ($230 \mathrm{mV}$ ). Despite the inhibiting effect of the metals microbial metabolism didn't stop, which was signified by continuous hydrogen production.

In four days after metals adding the metabolical processes in the experimental (exposed) variant were more active than in the control ones. It was shown by more active gas production $(850 \mathrm{ml} /$ day compared to $130 \mathrm{ml} /$ day in control ones) and more active substrate destruction (visually observed).

Adding of metals did not inhibit microbial biomass growth (Fig. 3). After adding of metals in 24 hours the optical density in both control and experimental variants increased from 2.8 to 4.5 and from 3.5 to 4.6 units accordingly, and was decreasing gradually in the next two days.

Thus, we can make the following generalizations for the effect of six representative metals ( $\mathrm{Cu}(\mathrm{II}), \mathrm{Co}(\mathrm{II}), \quad \mathrm{Ni}(\mathrm{II}), \mathrm{Hg}(\mathrm{II}), \mathrm{Cr}(\mathrm{VI})$, $\mathrm{Fe}(\mathrm{III})$ ) on spore-forming microbial community's metabolism. The Bacillus-Clostridium community is able to perform active metabolism in the presence of the mentioned metals.

After adding of the metals there was a quick ( in one hour) decrease in their concentration in the medium more than in five times. Thus in 30 minutes all $\mathrm{CrO}_{4}{ }^{2-}$ was completely removed from the solution. The concentration of $\mathrm{Fe}(\mathrm{III})$ in one hour was reduced almost 10 times (from $20 \mathrm{mg} / 1$ to 2.5 mg/l) (Fig. 4).

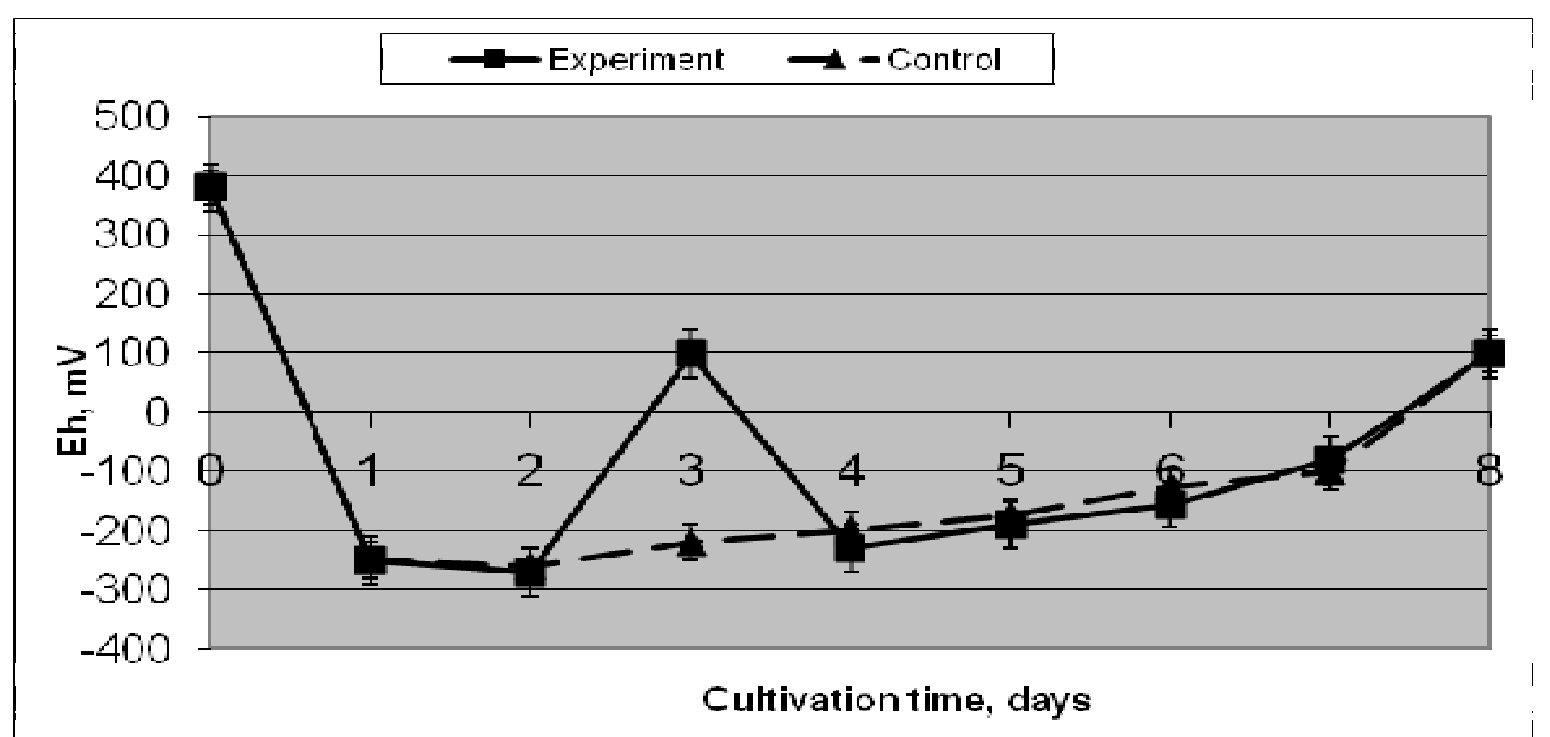

Fig. 1. Eh dynamics in the cultivation process. Metals are added on the third day of cultivation to experimental flasks. 


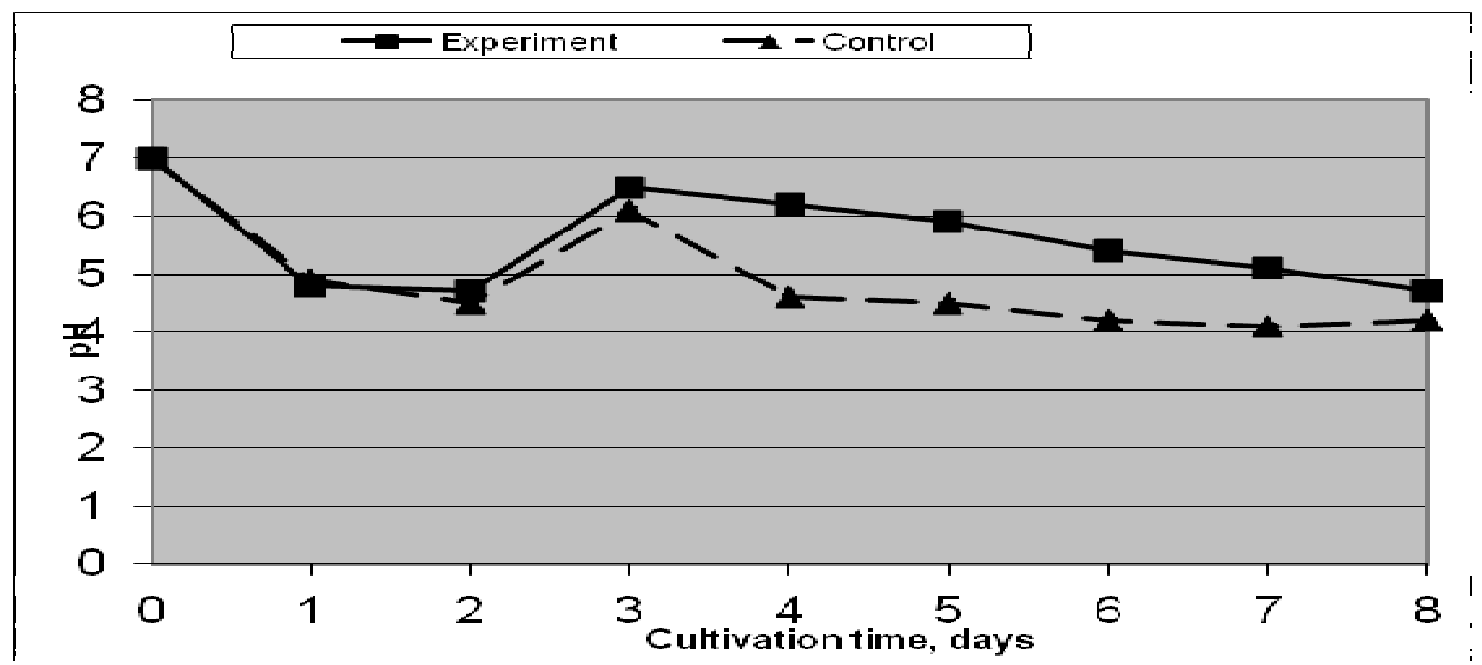

Fig. 2. pH dynamics in the cultivation process. Metals are added on the third day of cultivation to experimental flasks.

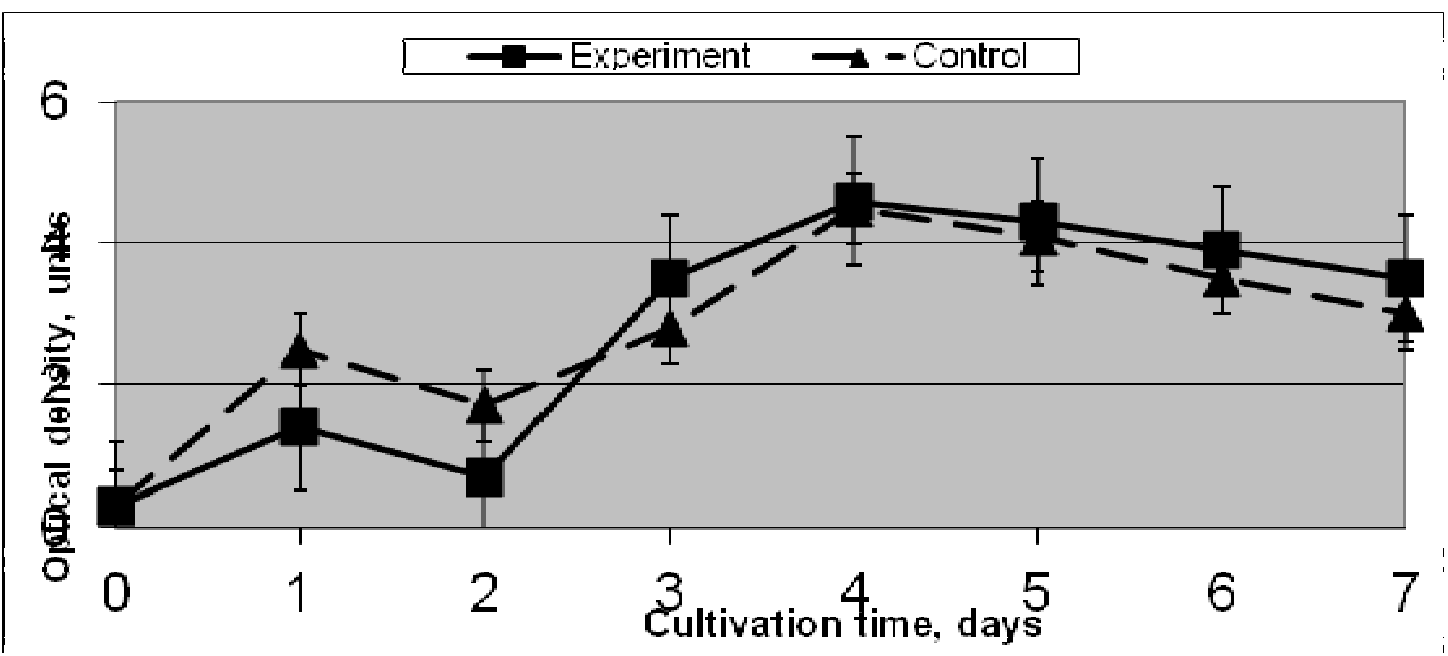

Fig. 3. Optical density dynamics in the cultivation process. Metals aree added on the third day of cultivation to experimental flasks.

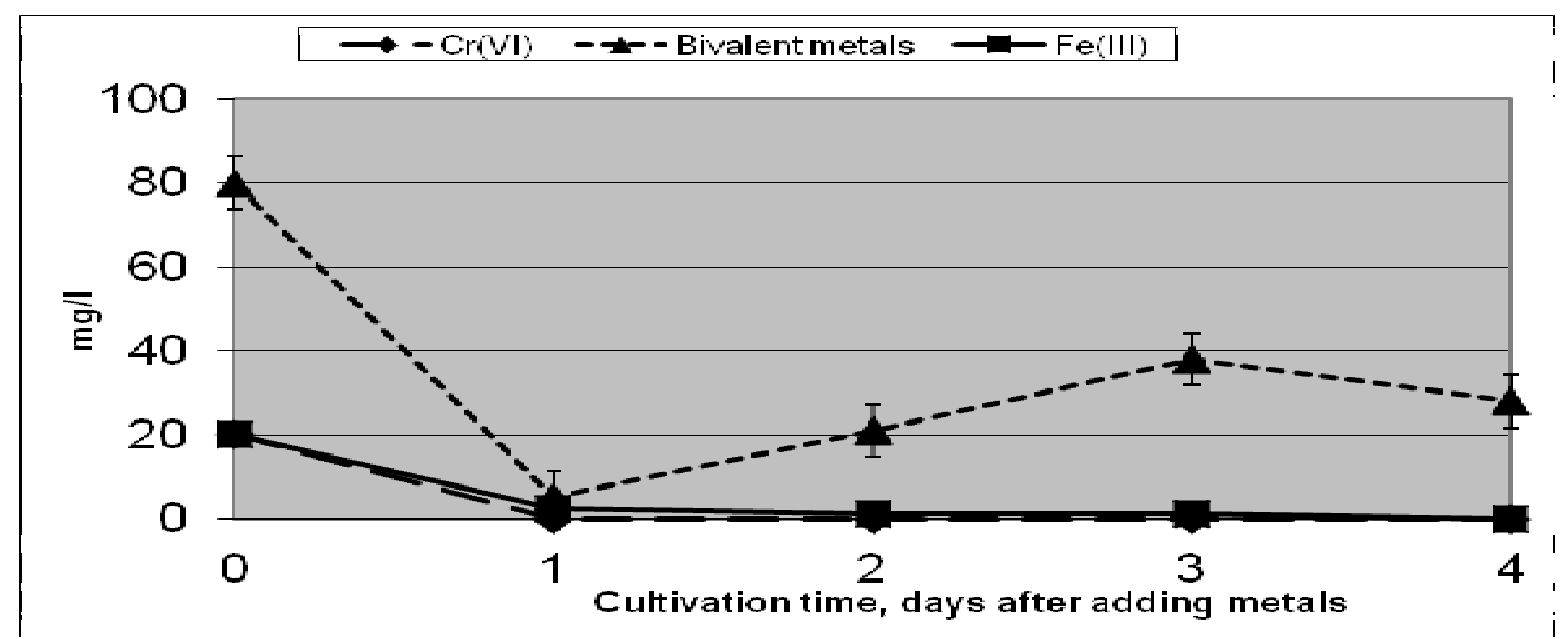

Fig. 4. Metal extraction from the medium starting from the day of adding. 
The general concentration of bivalent metals $\left(\mathrm{Cu}^{2+}, \mathrm{Hg}^{2+}, \mathrm{Co}^{2+}, \mathrm{Ni}^{2+}, \mathrm{Fe}^{2+}\right)$ in 30 minutes reduced on $10 \mathrm{mg} / \mathrm{l}$ and equaled $70 \mathrm{mg} / \mathrm{l}$. On the next day the concentration of these metals decreased to the level of $5 \mathrm{mg} / \mathrm{l}$. Thus, in one day there was the extraction of metals from the solution to $96 \%$. Nevertheless three days later the increase of metal concentration was observed on the level of $38-28 \mathrm{mg} / 1$ (Fig. 4). This required a special discussion. From the thermodynamical characteristics of the observed metal appeares that in the process of interaction with metabolically active microorganisms they inevitably are extraxted from the solutions. Combined action metals $\left(\mathrm{Hg}^{2+}, \mathrm{Cu}^{2+}\right)$ are reduced to insoluble compounds. Substitute metals under neutral conditions form insoluble compounds like hydroxides, sulphides, carbonates etc. But, if the medium is exposed to a "secondary" acidification then the mentioned above metal compounds under $\mathrm{pH}=4,0 \ldots 5,0$ turn back into the soluble form.

The obtained results confirm the previously described possibility of non-adapted microorganisms to show different mechanisms of interaction with metals. Here we can observe reduction (Fe (III) $\rightarrow$ $\mathrm{Fe}$ (II), $\mathrm{Cr}(\mathrm{VI}) \rightarrow \mathrm{Cr}$ (III)) and immobilisation and mobilisation depending on the medium $\mathrm{pH}$ (bivalent metals: $\left.\mathrm{Cu}^{2+}, \mathrm{Co}^{2+}, \mathrm{Ni}^{2+}, \mathrm{Hg}^{2+}\right)$.

The data obtained assume the following conclusions:

1. Natural soil microbial communities are resistant to the most toxic metals $\left(\mathrm{Cu}^{2+}, \mathrm{Hg}^{2+}, \mathrm{Ni}^{2+}\right.$, $\mathrm{Co}^{2+}, \mathrm{CrO}_{4}^{2-}$ and $\mathrm{Fe}^{3+}$ ) under high concentration of the latter $-120 \mathrm{mg} / 1$. Microorganisms are not only resistant to the metals but they are also able to extract them from the solutions (up to $96 \%$ ).

2. the presence of the metals in the medium does not lead to stopping of microbial destruction of model food waste and hydrogen production.

3. The principal possibility of using natural soil Bacillus-Clostridium community for simultaneous food waste neutralisation, hydrogen synthesis and most toxic metals extracting was proven.

4. The data obtained testify that the resistance of natural microbial communities to metals are much higher than it was known.

5. the obtained regularities are the basis for the development of new combined biotechnologies, allowing simultaneously to destroy ecologically hazardous solid food waste, treat metalcontaminated sewages and obtain environmentally friendly energy source - hydrogen.

\section{References:}

1. Derek $\mathrm{R}$ Lovleya, John $\mathrm{D}$ Coates, Bioremediation of metal contamination, Volume 8, Issue 3, June 1997, Pages 285-289

2. Geoffrey M. Gadd, Microbial influence on metal mobility and application for bioremediation// Geoderma Volume 122, Issues 2-4, October 2004, Pages 109-119

3. G. De Gioannis, A. Muntoni, A. Polettini, R. Pomi, A review of dark fermentative hydrogen production from biodegradable municipal waste fractions, Waste Management 33 (2013), 1345-1361

4. J. F. Blais, R. D. Tyagi, J. C. Auclair and C. P. Huang, Comparison of Acid and Microbial Leaching for Metal Removal from Municipal Sludge, Water Science \& Technology, Vol 26 No 12, P. 197-206 (C) IWA Publishing 1992

5. Lurie Y.Y. The handbook on analytical chemistry, Moscow, Chemistry, 1979, 480.

6. Melanie J Brown, J.N Lester, Metal removal in activated sludge: the role of bacterial extracellular polymers, Water Research Volume 13, Issue 9, 1979, Pages 817-837

7. Modern microbiology. Procariotes: 2 volumes, Lengler Y., Drevs G., Shlegel G, Moscow, Mir, 2005, 363-368.

8. Prytula I., Regularities of molecular hydrogen production by spore-forming bacteria during food waste fermentation, autoref. $\mathrm{PhD}$ thesis 03.00.07, Kiev, 2016, 22 p.

9. Sarabjeet Singh, Ahluwalia, Dinesh Goyal, Microbial and plant derived biomass for removal of heavy metals from wastewater, Bioresource Technology Volume 98, Issue 12, September 2007, Pages 2243-2257

10. Sendel E. Colorimetry methods of metal traces measurement, Moscow, Mir, 1964, 899.

11. Tashyrev A.B., Theoretical aspects of microorganisms and metals interaction. Microbial accumulation of metals, based on their sthereochemical analogy to macroelements, Microbiol. Journal, 1994, Vol. 56, 89-100.

12. Tashyrev A.B., Microorganisms and metals interaction, Microbiol. Journal, 1995, Vol. 57, № 2, $95-104$.

13. Transport and the Hydrogen Economy, internet source: http://www.worldnuclear.org/information-library/non-power-nuclearapplications/transport/transport-and-the-hydrogeneconomy.aspx]. 


\title{
ЕКСТРАКЦИЯ НА ТОКСИЧНИ МЕТАЛИ В ПРОЦЕСА НА ФЕРМЕНТАЦИЯТА НА КАРТОФИ
}

\author{
Сиома И.Б., Таширев А.Б., Говоруха В.М., Прекрасна Й.П.
}

Резюме: Съгласно разработената от нас термодинамична прогноза беше извършено проучване върху взаимодействието на съобществото Bacillus-Clostridium и шест подбрани метала. Към тези метали се отнасят: окислители $\left(\mathrm{CrO}_{4}{ }^{2-}\right)$, заместители $\left(\mathrm{Ni}^{2+}, \mathrm{Co}^{2+}\right)$ и метали за въздействие, които комбинират характеристиките както на окислителите, така и на заместителите $\left(\mathrm{Cu}^{2+}, \mathrm{Hg}^{2+}, \mathrm{Fe}^{3+}\right)$.

Естествените микробни съобщества, произвеждащи водород в почвата, изглеждат устойчиви на металите в обща концентрация от $120 \mathrm{mg} / \mathrm{l}$ и също така могат да извличат тези метали от разтвора (до 96\%).

Получените закономерности са основа за разработването на нови комбинирани биотехнологии, които позволяват да се неутрализират екологично опасни отпадъци от хранителни продукти, да се третират замърсените с метали отпадни води и същевременно да се получи екологично чист енергиен източник водород.

Ключови думи: резистентни на метали съобщества, третиране на отпадни води, унищожаване на токсични отпадъци

\section{I.B. Sioma,}

Department of biology of extremophilic microorganisms Zabolotny Institute of Microbiology and Virology of NAS of Ukraine Address: 03143, Ukraine, Kyiv, Zabolotnogo str., 154

e-mail: irasioma82@gmail.com

\section{A.B. Tashyrev, Professor, Dr Sci,}

Head of the department of biology of extremophilic microorganisms Zabolotny Institute of Microbiology and Virology of NAS of Ukraine Address: 03143, Ukraine, Kyiv, Zabolotnogo str., 154

Telephone: +38(044)5263297

e-mail: tach2007@ukr.net 